\title{
Ordering Institutions: The Judicial Function of the Permanent Court of International Justice in Relation to Interwar Organizations
}

\author{
Philip Burton ${ }^{1}$ \\ University of Bristol Law School, University of Bristol, Bristol, United Kingdom \\ nw19925@bristol.ac.uk
}

\begin{abstract}
The Permanent Court played a vital role in the emergence of the law of international organizations. Existing accounts of this development focus on the Court's conception of organizations. This paper argues that this interpretation underappreciates the controversy regarding the performance of the Permanent Court's judicial function and its place within the inter-war institutional order. Crucially, it is claimed that initially the Permanent Court adopted the perspective of an authoritative interpreter, limiting the scope for recognising the autonomy of organizations. However, the Court began to adopt a more restrained conception of its judicial function and recognised that international organizations possessed a form of compétence de la compétence. This recognition paved the way for a 'law of international organizations' to emerge, but, crucially, was not based on any revised understanding of what it meant to 'be' an international organization, but rather, on what it meant to 'be' an international court.
\end{abstract}

\section{Keywords}

history of the law of international organizations - judicial development of the law of international organizations - League of Nations - permanent court of international justice - the powers of international organizations - autonomy of international organizations - fragmentation

1 University of Bristol. PhD (Manchester), LLM (Amsterdam), LLB (Glasgow). 
Historically, judicial development has been the central trope in legal writing on international organizations. ${ }^{2}$ It is no coincidence that the study of the law of international institutions emerged as a discrete field at the same time as international courts delivered a series of pronouncements - Reparations,$^{3}$ Certain expenses ${ }^{4}$ and Van Gend en Loos $^{5}$ - which heralded the arrival of international organizations as new subjects of law, as "living" creatures with the capacity to evolve independently of the intentions of their creators and supposed masters. Nevertheless, while this way of thinking about international organizations persists in the textbooks and teaching of the field, scholarship has largely moved on. The "proliferation" of institutions, and the diversity of their practices, has abounded while the flow of grand judicial pronouncements has reduced to a trickle. Ideas of governance, administration and bureaucracies now dominate. ${ }^{6}$ The extent to which these frames can or ought to be reconciled to the classic doctrines of the law of international organizations remains to be seen. ${ }^{7}$

The historical turn in the study of international institutions has coincided with this shifting analytical locus. It is therefore unsurprising that the rich abundance of recent historical scholarship on international organizations reflects the currently vogue ways of thinking about international organizations. ${ }^{8}$

2 The leading example of this genre is Elihu Lauterpacht, The Development of the Law of International Organizations by the Decisions of International Tribunals, Recueil des Cours de L'Academie de Droit International de la Haye, 152, 381-478. See, also, Tetsuo Sato, Evolving Constitutions of International Organizations: A Critical Analysis of the Interpretative Framework of the Constituent Instruments of International Organizations (Brill Nijhoff, 1996); Julian Arato, 'Treaty Interpretation and Constitutional Transformation: Informal Change in International Organizations' (2013) 38 Yale J. Int'l L. 289.

3 Reparation for Injuries Suffered in the Service of the United Nations [1949] ICJ Reports 174 ('Reparations').

4 Certain expenses of the United Nations (Article 17, paragraph 2, of the Charter) (Advisory Opinion) [1962] ICJ Reports 151 ('Certain Expenses').

5 NV Algemene Transport- en Expeditie Onderneming van Gend \& Loos v Netherlands Inland Revenue Administration Judgment of the Court 5 February ${ }_{1963}$ Case 26-62.

6 Michael Barnett and Martha Finnemore, Rules for the World: International Organizations in Global Politics (Cornell University Press, 2004); Benedict Kingsbury, Nico Krisch and Richard B Stewart, 'The Emergence of Global Administrative Law' (2005) 68(3/4) Law and contemporary problems 15; Armin von Bogdandy et al (eds), The Exercise of Public Authority by International Institutions: Advancing International Institutional Law (Springer-Verlag, 2010); Jan Klabbers, Anne Peters and Geir Ulfstein, The Constitutionalization of International Law (OUP Oxford, 2011).

7 See, eg, Jan Klabbers, 'Contending Approaches to International Organizations: Between Functionalism and Constitutionalism' in Jan Klabbers and Asa Wallendahl (eds), Research Handbook on the Law of International Organizations (Edward Elgar Publishing, 2011) 3.

8 See, for example, Antony Anghie, Imperialism, Sovereignty and the Making of International Law (Cambridge University Press, $1^{\text {st }}$ ed, 2005); Guy Fiti Sinclair, To Reform the World: 
Concerns, for example, about the influence of experts in global governance have been accompanied with the discovery that experts were central to the operation of the League. ${ }^{9}$ As such, we have arrived at a position where we know more about the Permanent Mandates Commission of the League of Nations, and its place in the genealogies of governance and economic development, than we do about the ways that the reasoning of the Permanent Court helped foment the idea of a law of international organizations. ${ }^{10}$

That the Permanent Court did so appears unambiguous both from the literature and from the liberal citation of its opinions by its successor, the ICJ. Clear antecedents of the classic doctrines of separate personality, implied powers and practice of the organization can be found in the Permanent Court's jurisprudence. The ICJ has cited its predecessor's reasoning in support of both its most expansive and restrictive interpretations of the powers of international organizations. ${ }^{11}$ Georg Scwarzenberger, one of the earliest holders of an academic chair dedicated to the study of institutions was, in 1949, able to observe the Permanent Court had authored 'a far from negligible body of international institutional law.'12 However, the content and nature of this body of law has not been subject to sustained analysis.

Such recent scholarship that exists on the Permanent Court's contribution to the law of international organizations tends to share a common narrative. According to this narrative, the Court initially failed to grasp "what was going

International Organizations and the Making of Modern States (Oxford University Press, 2017) ('To Reform the World').

9 See, for example, Patricia Clavin, Securing the World Economy: The Reinvention of the League of Nations, 1920-1946 (OUP Oxford, 2013); Barnett and Finnemore (n 5); David Kennedy, A World of Struggle: How Power, Law, and Expertise Shape Global Political Economy (Princeton University Press, 2018).

10 The Permanent Mandates Commission has been a central focus on critical historical scholarship in part because it offers such clear evidence of the continuities from colonial governance to modern development. See, for example, Balakrishnan Rajagopal, International Law from Below: Development, Social Movements and Third World Resistance (Cambridge University Press, 2003); Anghie (n 7); Ntina Tzouvala, Capitalism as Civilisation: A History of International Law (Cambridge University Press, 2020). However, this strand of scholarship has been critiqued by Pedersen, the leading historian of the PMC, for reframing the PMC as a 'kind of world bank in embryo'. See Susan Pedersen, 'Back to the League of Nations' (2007) 112 (4) American Historical Review 1091, 1104.

11 Reparations (n 2) 182-183; Legality of the Use by a State of Nuclear Weapons in Armed Conflict (Advisory Opinion) [1996] ICJ Reports 66, 78-79 ('Legality of Nuclear Weapons').

12 Georg Schwarzenberger, Internationa Law: As Applied by International Courts and Tribunals, vol 1 (Steven and Sons Ltd, ${ }^{\text {st }}$ ed) 338. Nevertheless, Schwarzenberger acknowledged doubt regarding the generality of such principles, ibid 341. Georg Schwarzenberger, International Law: As Applied by International Courts and Tribunals, vol 1 (Steven and Sons Ltd, 1st ed) 338, quoted in Guy Fiti Sinclair, 'Towards a Postcolonial Genealogy of International 
on" with international organizations. This initial failure to grasp the nature of organizations was, through iterative opinions, overcome. The crude early attempts to solve legal problems concerning institutions were replaced by a more sophisticated set of analytics, capable of simultaneously reflecting the revolutionary nature of institutions and unharnessing their transformative potential. The reasoning which predated this shift is regarded as little more than naïve fumbling, as representative of a disciplinary "dark age" where nothing especially interesting happened.

It is undoubtedly the case that the Permanent Court's reasoning on international organizations at the start of the 1920 s was fundamentally different to its reasoning at the end of that decade. Complex questions about institutions were increasingly framed within doctrinal constructs that are recognisable to present-day lawyers. This article looks to challenge the dominant understanding as to how this change came about. Rather than looking for explanations for this change in a reconceptualization, a sudden realisation of the nature of international organizations, I posit that this transformation can best be understood as a consequence of the Court navigating an ambiguously defined and rapidly evolving institutional order while simultaneously negotiating its own function within it. By foregrounding ambiguities about the international judicial function and the structure of interwar international organization, it is hoped that fresh light can be cast on this disciplinary "dark age".

Seeking to portray this shift as reflexive, as a transformation in the way that the Court understood and discharged its function within a nascent institutional order, has implications beyond contributing to a more nuanced account of the emergence of the law of international organizations. Shifting attention away from the apparent nature of organizations, towards the Permanent Court's understanding of its place and function within a broader structure of international organization and the influence this understanding had upon the Court's articulation of the principles and presumptions of the law of international organizations helps expose the way these norms were contested and reveals how the solutions arrived at were historically contingent. The classic doctrines of law of international organizations are thus shown to be epiphenomenal; orientated by a set of assumptions that speak to the nature and structure of "international organization", rather than any properties, inherent or otherwise, of individual international organizations. ${ }^{13}$

Organizations Law' (2018) 31(4) Leiden Journal of International Law 841, $85^{2}$ ('Postcolonial Genealogy').

13 Regarding the wider and narrower meanings of the term 'international organizations', see Sinclair (n 11) 846-847. 
This article begins by briefly sketching out the understanding of the Permanent Court's contribution to the law of organization which is pervasive in current scholarship (section 1). The issue is then recontextualised within wider uncertainties regarding the structure of the interwar institutional order and the nature of the international judicial function (section 2). Section 3 elaborates the conceptual and methodological choices which underpin this study, in particular, the use of the compétence de la compétence principle as a heuristic. On this basis, the paper proceeds to chart the various conceptions of the international judicial function in relation to international institutions, demonstrating how the Court initially assumed the mantle of an authoritative interpreter (section 4). Section 5 explores the Eastern Carelia advisory opinion, presenting this case as a rupture both in the international order and in the Court's reasoning. The Court's subsequent embrace of a more modest understanding of its role regarding other institutions is explored in section 6 .

\section{The Dominant Account Regarding the Permanent Court's Influence upon the Law of International Organizations}

In recent years, there has been a resurgence of interest in the international institutions of the inter-bellum. In contrast to the first wave of histories penned during, or in the immediate aftermath of, the collapse of the League, ${ }^{14}$ 'the relevant question now is not "why the League failed" but rather the more properly historical question of what it did and meant over its twenty-five-year existence. ${ }^{15}$ Despite this renewal of interest in the subject, few studies have focused on the impact of the Permanent Court on the law of international organizations. ${ }^{16}$ In the absence of specialised studies, the question tends to be addressed by overarching works, which necessarily paint in broad strokes, or thematic studies with a narrow field of enquiry. Overwhelmingly, these studies

14 See, eg, Edward Hallett Carr, The Twenty Years' Crisis: 1919-1939 (Springer, 2016) ('The Twenty Years' Crisis, 1919-1939'); Egon Ferdinand Ranshofen-Wertheimer, The International Secretariat: A Great Experiment in International Administration (Carnegie Endowment for International Peace, 1945) ('The International Secretariat'); Francis P Walters, A History of the League of Nations (Oxford University Press, 1965).

15 Pedersen (n 9) 1092. Herren further distinguishes recent histories by pointing to the 'historiographical revolution' which 'has fostered interest in a historiography of global transcultural entanglements.' Madeline Herren, 'International Organizations, 1865-1945' in Jacob Katz Cogan, Ian Hurd and Ian Johnstone (eds), The Oxford Handbook of International Organizations (Oxford University Press, 2016) 91, 102.

16 Interestingly, Cedric Ryngaert et al (eds), Judicial Decisions on the Law of International Organizations (Oxford University Press, 2016) only contains a single commentary on a 
conform to the view that the Permanent Court, initially at least, failed to grasp the significance of international organizations but gradually came to appreciate their "special nature". 17

This account of the Permanent Court's impact on the law of international organizations is most forcefully presented in the writing of Jan Klabbers. Klabbers' paper, The Life and Times of the Law of International Organizations provides a good illustration of his thoughts on the subject. ${ }^{18}$ The article is intended to provide a 'helicopter view' of the development of the law of international organization, reviewing over a century of scholarly and judicial trends. ${ }^{19}$ This inevitability means that there is insufficient space for a full exposition of the argument regarding the Permanent Court but, as noted above, this is a recurring issue in scholarship on the subject. Acknowledging that ' $\mathrm{t}] \mathrm{h}$ he PCIJ, perhaps out of necessity, hesitantly laid the foundations for some of the more vital doctrines of the discipline, ${ }^{20}$ Klabbers characterises the Permanent Court's early engagement with international organizations as 'a period of search, of trying to come to terms, however hesitantly, with international organizations and their place in the grander scheme of things. ${ }^{21}$ The thesis advanced here is that this latter aspect, and indeed the relationship between the two, has been systematically underappreciated.

Klabbers' (critical) analysis focuses on this 'coming to terms' with the nature of international organizations. '[T] he Court's work on international organizations' according to Klabbers 'can be characterized as trying to get a handle on this new phenomenon without, however, being very successful at it.'22 In its early advisory opinions 'the Court hardly seems to be aware that there might be something special about international organizations. ${ }^{23}$ Over the course of the 1920s the Permanent Court came 'to realize that there might be more to international organizations than meets the eye. ${ }^{24}$ The analysis revolves

Permanent Court decision. Similarly, although several contributions are concerned with the law of international organizations in Malgosia Fitzmaurice and Christian J Tams, Legacies of the Permanent Court of International Justice (Martinus Nijhoff Publishers, 2013) none of the contributors tackle the subject directly.

17 Jan Klabbers, Advanced Introduction to the Law of International Organizations (Cambridge University Press, 3rd ed, 2015) 52 ('Advanced Introduction').

18 Jan Klabbers, 'The Life and Times of the Law of International Organizations' (2001) 70 Nordic J. Int'l L. 287 ('Life and Times'). A broadly similar account can be found in Klabbers, Advanced Introduction (n 16) 51-53.

19 Klabbers, 'Life and Times' (n 17) 288.

20 Ibid 290.

21 Ibid (emphasis added).

22 Ibid 295 .

23 Ibid.

24 Ibid. 
around the question of the nature of international organizations and suggests, implicitly at least, that the legal properties of organizations (as we understand them today) were already present, merely waiting to be discovered.

This narrative is echoed by a number of texts considering the period. Engström, whose writings on the Permanent Court revolve around the emergence of the modern powers doctrine, follows a broadly similar narrational arc. ${ }^{25}$ For Engström, it is unremarkable that the PCIJ [...] was somewhat hesitant in regarding the [International Labour Organization] as somehow different from a treaty construction. ${ }^{26}$ Despite its initial failure 'to identify any special characteristics of organizations,' the Permanent Court would go on to make 'a general characterization of the sources and extent' of the competence of organizations. ${ }^{27}$ Engström, sums up the crucial change as thus:

Whereas the Court in dealing with the ILO had focused on interpretation of the terms of the constituent instrument in order to find out what the drafters had intended the organization to do, the idea of an independent exercise of attributed powers changed this vocabulary into one of empowerment. $^{28}$

Likewise, Collins traces a similar shift, from bonded treaty-construct to autonomous institution, highlighting how '[t]he treaty framing was particularly evident in cases directly or indirectly addressing questions of the League's institutional competence, such as Eastern Carelia (1923) or Nationality Decrees (1923). ${ }^{29}$ However, 'by the late 1920 . . . it is clear that [the Permanent Court] ascribed a much greater weight of authority to the idea of international organisations as autonomous actors, thereby capable of a certain constitutional progression. ${ }^{30}$ This autonomy, and capacity for constitutional development, was

25 Viljam Engström, Constructing the Powers of International Institutions (Martinus Nijhoff Publishers, 2012) ('Constructing the Powers'). See also 'The early cases of the PCIJ had shown a certain hesitation on the part of the Court to establish a special status for international organizations beyond that of mere products of treaties.' Blanca Montejo, 'Interpretation of the Greco-Turkish Agreement of December 1st, 1926, [1928] Publ. PCIJ, Series B' in Cedric Ryngaert et al (eds), Judicial Decisions on the Law of International Organizations (Oxford University Press, 2016) 71, 77.

26 Engström, 'Constructing the Powers' (n 24) 29.

27 Ibid 33 .

28 Ibid.

29 Richard Collins, 'The League of Nations and the Emergence of International Administration: Finding the Origins of International Institutional Law' (2019) 71(2) Revista Espanola de Derecho Internacional 285, 289 .

Ibid. 
directly connected to 'the idea of institutions as being fundamentally imbued with the power to determine their own competence.'31 Again, 'what is most revealing in these cases was a hesitant search for and attempt to come to terms with the juridical nature of international institutions. ${ }^{32}$ These narratives not only share a common narrative of the shift in the PCIJ's thinking on international organizations, but also, in addition, diagnose the change as having arisen in relation to the understanding of the "nature" of international organizations.

Methodologically, the authors writing within this dominant narrative tend not to interpret the Permanent Court's decisions hermitically, but contextualise them within academic debates concentrated in continental Europe from the 189 os onwards. ${ }^{33}$ Thus, for example, Bederman finds the origins of the modern powers doctrine, not in the Permanent Court's reasoning, but in academic discourses thirty years earlier. ${ }^{34}$ The pre-eminent questions in this debate was whether international organizations were autonomous entities or whether states were the sole subjects of international law. It is worth noting that a number of future Permanent Court Judges can be counted amongst the participants of this debate. ${ }^{35}$ Naturally this debate intensified after 1919. On the one hand, scholars debated the nature of the League of Nations, seeking to understand it by references to a variety of legal forms. However, for the most part, the League was understood to be sui generis rather than as merely the most prominent example of a wider species. ${ }^{36}$ On the other hand, scholars, particularly those concerned with the law of treaties rather than institutions per se, began to systematically distinguish constituent instruments from other forms of treaties. ${ }^{37}$

Rather than reading the Permanent Court's construction of international organizations as an ontology of international organizations, this article focuses upon the structural and relational elements of the Court's reasoning. The analysis attempts to ground the legal construction of international organizations

31 Ibid.

32 Ibid 29o.

33 Klabbers, 'Life and Times' (n 17) 292-294; Engström, 'Constructing the Powers' (n 24) 29; Catherine Brölmann, The Institutional Veil in Public International Law: International Organisations and the Law of Treaties (Hart Publishing, 2007) 44-45; Collins (n 28) 290-292.

34 David J Bederman, 'The Souls of International Organizations: Legal Personality and the Lighthouse at Cape Spartel' (1995) 36 Va. J. Int'l L. 275, 343 et seq; 365-366.

35 For instance, regarding Anzilotti's contribution see Ibid 347-348. With respect to Huber, see Klabbers, 'Life and Times' (n 17) 296.

36 Sinclair, 'Postcolonial Genealogy' (n 11); Brölmann (n 32 ) 61.

37 Arnold D McNair, 'The Functions and Differing Legal Character of Treaties' (1930) 11 Brit. YB Int'l L. 100, 100; Hersch Lauterpacht, 'The Covenant as the Higher Law' (1936) 17 Brit. YB Int'l L. 54, 64-65. 
within the ambiguous architecture of the interwar institutional order. In doing so particular emphasis will be placed on the uncertainties regarding the ambivalent relations of authority between the Court and other institutions, and the ways that the Court sought to exercise this authority. By focusing on the Court's role in, and understanding of, the interwar institutional order, I want to demonstrate that the fundamental transformation in the Permanent Court's reasoning was reflexive, pertaining to its own judicial function rather than the nature of international organizations. Undoubtedly this resulted in a different way of seeing international organizations. The orientation provided by this shift in perspective provided the normative content of the modern law of international organizations, supplying its principles and presumptions the "tilt" of the field.

\section{2 \\ Authority, Interpretation and the Compétence de la Compétence Principle}

In this section I want to take forward one of the claims raised by Collins, that the Court recognized that institutions were fundamentally imbued with the power to determine their own competence. ${ }^{38}$ This is the key issue that I want to focus on. The issues placed before the PCIJ regarding international organizations did not concern whether or not legal powers existed, which is, in my view at least, the question that the attributed/implied powers approaches seek to resolve. ${ }^{39}$ Rather, the Court was repeatedly faced with the question of whether the utilisation of unambiguously existing powers fell within the competence of organizations; their jurisdiction, if you will. The arc I hope to convey in the analysis of the Permanent Court's decisions can thus be restated as a movement from the Court as an authoritative interpreter (ascribing little 'semantic authority' 40 to the interpretations arrived at by the institutions themselves), towards a more restrained, pluralistic conception of the judicial function accompanied by a recognition that other institutions possessed a form of compétence de la compétence.

38 Collins (n 28) 289.

39 Aside from the compétence de la compétence principle which the Court found to be implied in the context of the advisory jurisdiction and (more contentiously) to the ILO in Personal work (see below), the sole instance whereby the Court considered the existence of legal powers concerned the European Commission of the Danube's ability to promulgate policing regulations for ports.

40 See, eg, Ingo Venzke, How Interpretation Makes International Law: On Semantic Change and Normative Twists (OUP Oxford, 2012). 
The compétence de la compétence principle is the most venerable in international institutional law. A paradigmatic feature of a truly horizontal legal order is the right, held by subjects, of auto-interpretation. The rise of arbitration, initially within narrowly confined boundaries, curbed this right: states agreed to accept the interpretation of an arbitration panel as binding. The compétence de la compétence principle made this process effective by enabling arbitral panels to render authoritative interpretations regarding whether or not particular facets of a dispute fell within the compromis. ${ }^{41}$ Acceptance of the principle grew incrementally and, initially, it rested on the consent of the parties, meaning its essential object could be easily frustrated..$^{42}$ By the end of the $19^{\text {th }}$ century, the principle was increasingly regarded as the default position and featured in both the Institute de droit internaitonale's model rules for arbitration and the Permanent Court of Arbitration's statute. ${ }^{43}$ The vesting of the compétence de la compétence in the PCIJ with regard to the contentious jurisdiction is unsurprising.

The applicability of the compétence de la compétence principle to international organizations is more complex and contested and there are a variety of reasons why this is the case. There is, for example, a strand of 'judicial essentialist' thinking which is rooted in the ideal of courts as the ultimate arbiters of legality: only a court can pronounce with any finality on questions of legal interpretation. ${ }^{44}$ There is also a related issue concerning the state of adjudication within modern international law, in particular, the absence of any general court with compulsory jurisdiction. As such, there has been a reticence to inadvertently transform, for example, mechanisms of (non-judicial) pacific settlement into forms of compulsory adjudication. ${ }^{45}$ Similarly, explicit recognition

41 For an overview of this development, see Ibrahim FI Shihata, The Power of the International Court to Determine Its Own Jurisdiction: Competence de La Compétence (Springer, 2013) 10 et seq ('The Power of the International Court to Determine Its Own Jurisdiction').

Tom Bingham, 'The Alabama Claims Arbitration' (2005) 54(1) International \& Comparative Law Quarterly 1.

43 Ibid 14-19. See Article 14, Institut de droit internationale's Draft Regulations on Arbitral Procedure (1874); Article 48, Hague Convention for the Settlement of International Disputes, opened for signature 29 July 1899, entered into force 4 September 190o, UKTS 9 (1901) ('1899 Hague Convention').

44 As per Judge Fitzmaurice, 'But where the matter turns, and turns exclusively, on considerations of a legal character, a political organ, even if it is competent to take any resulting action, is not itself competent to make the necessary legal determinations on which the justification for such action must rest. This can only be done by a legal organ competent to make such determinations.' Legal Consequences for States of the Continued Presence of South Africa in Namibia (South West Africa) notwithstanding Security Council Resolution 276 (1970) (Advisory Opinion) [1971] ICJ Reports 16, 299 ('Namibia').

45 Compare the approaches of the Permanent Court in Nationality Decrees Issued in Tunis and Morocco, Great Britain v France (Advisory Opinion) [1924] PCIJ Series B No. 4 Premanent 
that institutions, through either minority-composed or majority voting organs, can bind all members through their interpretations of foundational texts chafes against the creed of state consent. Debates regarding the reviewability of acts of organizations further muddy the waters. To a greater or lesser extent, each of these concerns is reflective of dichotomous thinking regarding interpretation in international law: ultimate say regarding the meaning of texts and norms should either rest with courts (disinterested guardians of legality) or states (principal subjects of international law). Nevertheless, despite these principled objections, it is near universally recognised amongst contemporary scholars of international organizations that organizations possess some form of compétence de la compétence. ${ }^{46}$ As the ICJ declared in Certain expenses 'each organ must, in the first place at least, determine its own jurisdiction.'47 However, as applied to international organizations the principle is operational rather than legal, its normativity presumptive and incremental rather than absolute. ${ }^{48}$

Despite these ambivalences, I think it is useful to persist with the compétence de la compétence principle. Its presence or absence has the virtue of yielding insights into the nature and location of interpretative authority within an institutional order. We can therefore use it to construct a basic typology for quantifying institutional orders: they may be political or legal in character, whereby

Court of International Justice No. 2, 25-26 ('Nationality Decrees'); Mavrommatis Palestine Concessions (Greece v United Kingdom) (Jurisdiction) [1924] PCIJ Series A No. 2 16-17 ('Mavrommatis'). Ole Spiermann, International Legal Argument in the Permanent Court of International Justice: The Rise of the International Judiciary (Cambridge University Press, 2005) 157-159; 209 ('International Legal Argument').

46 Viljam Engström, 'Powers of Organizations and the Many Faces of Autonomy' in Richard Collins and Nigel D White (eds), International Organizations and the Idea of Autonomy: Institutional Independence in the International Legal Order (Routledge, 2011) 213, 218. More generally, see Catherine Brölmann, 'Specialised Rules of Treaty Interpretation: International Organizations' in Duncan B Hollis (ed), The Oxford Guide to Treaties (Oxford university press, 2012) 507; Louis Sohn, 'Interpreting the Law' in Oscar Schachter and Christopher C Joyner (eds), United Nations Legal Order (Cambridge University Press, 1995); José E Alvarez, 'Constitutional Interpretation' in Jean-Marc Coicaud and Veijo Aulis Heiskanen (eds), The Legitimacy of International Organizations (United Nations Publications, 20o1). Cf James S Watson, 'Autointerpretation, Competence, and the Continuing Validity of Article 2 (7) of the UN Charter' (1977) 71(1) American Journal of International Law 6o.

47 Certain expenses $(\mathrm{n} 3), 168$.

48 See, eg, "Resolution WHA46.40 itself, adopted, not without opposition, as soon as the question of the legality of the use of nuclear weapons was raised at the WHO, could not be taken to express or to amount on its own to a practice establishing an agreement between the members of the Organization to interpret its Constitution as empowering it to address the question of the legality of the use of nuclear weapons." Legality of Nuclear Weapons (n 10) 81 . 
interpretative authority is distributed amongst a range of institutional forms or concentrated in the hands of a judicial elite. Institutional orders may also be hierarchical or pluralistic. In the former superior organs hold the authority to set aside the decisions of inferior organs, in the latter interpretative authority is widely dispersed. This basic typology, would, therefore, look something like this:

\begin{tabular}{lll}
\hline & Political & Legal \\
\hline Hierarchical & $\begin{array}{l}\text { Political-hierarchical } \\
\text { (supreme authority vested in } \\
\text { political organ) }\end{array}$ & $\begin{array}{l}\text { Legal-hierarchical (supreme } \\
\text { authority vested in legal } \\
\text { organ) }\end{array}$ \\
Plural & $\begin{array}{l}\text { Political-plural (interpre- } \\
\text { tative authority dispersed } \\
\text { widely and diversly) }\end{array}$ & $\begin{array}{l}\text { Legal-plural (interpretative } \\
\text { authority dispersed widely } \\
\text { amongst a single type } \\
\text { (legal) of institution) }\end{array}$ \\
& &
\end{tabular}

Using the compétence de la compétence principle also has the virtue of descriptive specificity. As already mentioned, by and large, the disputes concerning institutions which were brought before the PCIJ concerned the delimitation of the sphere of appropriate activity. A more general framing (such as "interpretative authority") or a more conventional framing (attributed/implied powers), elide the nature of this specific and recurring question. Lastly, it is (mildly) provocative: I think it is conceptually productive to disrupt the apparently solid categories of international organization and international court. What all this boils down to is that the compétence de la compétence principle can be simultaneously seen as an attribute of international organizations and an indicator of the structure of the institutional order and the role of the Permanent Court within it.

The crude arc that the remainder of this article seeks to portray is a clockwise movement from the political-hierarchical vision which dominated the Versailles Conference, through the legal-hierarchical informed posture which the Court adopted in its earliest advisory opinions, towards a more pluralistic conception of the international institutional order. I describe this arc as crude because I want to avoid conveying a deterministic or linear sense of progress; each "type" was subjected to contestation and compromise. Moreover, in light of the ongoing controversies regarding whether or not international organizations possess compétence de la compétence, the extent to which there has ever 
been a passage between legal and political pluralism is not entirely clear. Nor is it clear whether these types are fully distinguishable within the periodisation adopted in this study. I do think, however, that there is enough of a gesture in this direction, complex and contradictory as it may be, to warrant its inclusion in this narration. What I'm really interested in is how the prevailing tendencies towards one type or another led to different ways of framing international organizations in legal forms. Exposing this relationship, between broader conceptions of institutional order and specific ways of thinking about individual organizations, is the key ambition of this article.

International Organization as Conceived by the Drafters of the Covenant

The adoption of the Covenant of the League was 'an attempt to organise the hitherto unorganised community of states by a written constitution. ${ }^{49}$ This was, of course, to be realised by limiting recourse to force through prescriptive rules and the establishment of mechanisms of dispute settlement. It was also to be realised through the creation of new, and rationalisation of existing, bureaux, conferences, public unions, and so on, in order to entangle states' interests and collectively resolve common challenges. What this meant was that the "move to institutions" did not only entail the organization of the community of states but also represented an attempt to organize the community of institutions which had emerged during the late $19^{\text {th }}$ and early $20^{\text {th }}$ century. However, early visions for the League, in particular the vision advanced by the League's most prominent advocate, Woodrow Wilson, were thick on principle but strikingly thin regarding the institutional mechanisms by which these principles would be realised. This section attempts to sketch out the vague visions of institutional order which prevailed during the drafting of the Covenant and the Statute of the PCIJ. The analysis focuses on two particularly salient issues. Firstly, it examines the centralising impulse, the ambition to create a unified, hierarchical vision of international organization. Secondly, it traces the relatively low priority ascribed to the establishment of a court within this system and the fundamental ambiguities regarding the place of what became the PCIJ within this system. This analysis furnishes evidence of the desire to create a political-hierarchical institutional order, with a Council of "Great Powers"

49 Lassa Oppenheim, International Law: A Treatise, vol 1 (Longmans Green \& Co, 3rd Edition, 1920) 269. See also Quincy Wright, 'Effects of the League of Nations Covenant' (1919) 13(4) American Political Science Review 556, 556. 
sitting spider-like, at the centre of the web. This section concludes by briefly surveying how this centralising impulse fractured almost immediately after the delegates left Paris.

\subsection{Organizing the community of institutions}

The structure of the contemporary international order has, of course, been subjected to fierce debates over the past decade. By contrast, the negotiations at Versailles were characterised by a consensus that the "proliferation" of various institutions that had emerged during the latter half of the nineteenth century should be rationalised under the auspices of the League. By November 1918, this was already central to official British thinking about the mooted League. Smuts, the South African representative on the Imperial War Council, spelled out the importance of wider international cooperation. It would be insufficient, according to Smuts, for the League to be 'a sort of deus ex machina, called in in very great emergencies when the spectre of war appears' ${ }^{50}$ Rather, the League 'must function so strongly in the ordinary peaceful intercourse of States that it becomes irresistible in their disputes. ${ }^{51}$ This was to be realised through the encompassment of existing bureaux within the League as well as the establishment of new committees to tackle 'thorny subjects'. ${ }^{52}$ According to Smuts, "[w]ater-tight compartments and partition walls between the nations and the continents have been knocked through, and the new situation calls for world-government. ${ }^{33}$ This centralising, rationalising impulse was also reflected in a Foreign Office Memorandum which called for a strong, permanent secretariat. ${ }^{54}$ The British envisaged a dual role for the Secretariat: it was to facilitate the deliberations regarding "high politics" at the Council while organizing the works of the international bureaux. In this sense, 'it would be a Secretariat of Secretariats. ${ }^{55}$ The Cecil Plan, initially formulated in late 1918 and refined in January 1919, reflected this position, making provision for the

$5^{\circ}$ Jan Christiaan Smuts, The League of Nations; a Practical Suggestion (London Hodder and Stoughton, 1918) 8.

$51 \quad$ Ibid.

$52 \quad$ Ibid 43.

53 Ibid.

54 'A Memorandum Prepared for the Consideration of the British Government in Connexion with the Forthcoming Peace Settlement', as reproduced in Alfred Zimmern, The League of Nations and the Rule of Law (MacMillan, 1939) 197-209, 205. The emphasis on a strong secretariat would be a persistent objective of the British negotiators at Versailles. David $\mathrm{H}$ Miller, The Drafting of the Covenant, vol 1 (Putnam, 1928) 57 ('Drafting the Covenant Vol. 1').

Zimmern (n 53) 194. 
Secretariat to direct the activities of 'International Bodies'. ${ }^{56}$ While the text of the provision was modified through subsequent drafts, its core ethos was never seriously challenged. The final text of Covenant provided that:

There shall be placed under the direction of the League all international bureaux already established by general treaties if the parties to such treaties consent. All such international bureaux and all commissions for the regulation of matters of international interest hereafter constituted shall be placed under the direction of the League.

All such international bureaux and all commissions for the regulation of matters of international interest hereafter constituted shall be placed under the direction of the League... ${ }^{57}$

Even the International Labour Organisation, the constitution of which was laid down separately in Part XIII of the Treaty, was intended to be incorporated into the structure of the Secretariat. 58

\subsection{The Court and its place in the scheme of international organization}

Given the prominence of the international movement for arbitration before the war, and the attention dedicated to the PCIJ after its establishment, it is remarkable how little thought was given to a judicial body in the drafting of the Covenant. Wilson's antipathy towards lawyers in general and legalistic Republican internationalism in particular meant that he had very little time for the subject and resisted attempts to include a court late into the spring of 1919. ${ }^{59}$ Colonel House, Wilson's intimate advisor, had included a remarkably ambitious plan for an 'International Court' in his July 1918 Draft, which would have granted the Court jurisdiction over conventional international legal disputes, 'matters of commerce', and questions that the organs of the proposed League submitted to it. ${ }^{60}$ However, through-out Wilson's own drafts,

56 David H Miller, The Drafting of the Covenant, vol 2 (Putnam, 1928) 62 ('Drafting the Covenant Vol. 2').

57 Article 24, Covenant of the League of Nations, 28 June 1919, 108 LNTS 188 (entered into force 10 January 1920) ('The Covenant').

58 Martin David Dubin, 'Transgovernmental Processes in the League of Nations' [1983] International Organization 469, 482-483.

59 See, generally, David S Patterson, 'The United States and the Origins of the World Court' (1976) 91(2) Political Science Quarterly 279.

6o Miller ( $\mathrm{n}_{55}$ ) 8. In the note accompanying the draft, House expanded upon the provision. "In the past I have been opposed to a court, but in working the matter out it has seemed to me a necessary part of the machinery. In time the court might well prove the strongest part of 
attention was devoted to the dispute resolution functions of the proto-Council. 'Arbitration' was simply stated as the alternative. Even in Spring 1919, when the task of establishing a 'permanent court of international justice' was assigned to the Council in the Hurst-Miller draft, ${ }^{61}$ Wilson remained reticent. On the eve of the formation of the Commission for the League of Nations ('League Commission'), Wilson proposed a final draft - deleting all mention of a Court which he hoped would form the basis of discussions. ${ }^{62}$ However, it was HurstMiller draft that would be taken forwards. ${ }^{63}$

The Miller-Hurst draft laid out the core of what was to become Article 14 with one crucial exception: it made no mention of the advisory jurisdiction. The advisory jurisdiction is essential if we are to understand the relationship between the Court and the wider system of international organization: once the Court was constituted as an independent body, the advisory jurisdiction was to remain the principal legal nexus between the League and the Court. It was also the principal jurisdictional basis for the Court to hear disputes regarding the law of international organizations. Despite the fact that antecedents figured in a range of proposals, the advisory jurisdiction appeared abruptly in the drafting of the Covenant. On the $18^{\text {th }}$ of March, Wilson and Cecil agreed to a revised draft of Article 14, expanding the competence of the Court to 'hear and determine' matters submitted by the parties and 'any issue referred to it by the [Council] or [Assembly].'64 This provision appeared to provide two

it." Miller (n 53) 13. Republican foreign policy elites tended to place far greater emphasis in legal institutions. See, eg, Martin David Dubin, 'Elihu Root and the Advocacy of a League of Nations, 1914-1917' (1966) 19(3) Western Political Quarterly 439. Democrat thinkers, reflecting the progressive tendencies of the age, placed greater emphasis on 'administration' as an agency for social change. For example, both Reinsch and Sayre approached institutions from the perspective of administration and went on to occupy high profile foreign policy jobs under Democrat governments. Paul Samuel Reinsch, Public International Unions: Their Work and Organization, a Study in International Administrative Law (Pub. for the World Peace Foundation, Ginn, 1911) ('Public International Unions'); Francis Bowes Sayre, Experiments in International Administration (Harper \& Bros., 1919). More generally, see Duncan Kennedy, 'Three Globalizations of Law and Legal Thought: 1850-200o' in David M Trubek and Alvaro Santos (eds), The New Law and Economic Development: A Critical Appraisal (Cambridge University Press, 2006) 19, 43.

61 Article 12 of the Hurst-Miller draft stated: "The Executive Council will formulate plans for the establishment of a Permanent Court of International Justice, and this Court will be competent to hear and determine any matter which the parties recognise as suitable for submission to it for arbitration under the foregoing Article." Miller (n 55) 234.

62 Ibid 145.

63 Miller, 'Drafting the Covenant Vol. 1 ' (n 53 ) 75 .

64 Miller ( $\left.\mathrm{n}_{55}\right)_{585}$. 
different means of seizing the Court's jurisdiction, rather than establishing two discrete functions.

The only real debate within the League Commission regarding the nature of the advisory function arose in response to a suggestion by Larnaude, one of the French participants. Larnaude proposed that the Court be invested with 'compétence pour entendre et juger:

a. Toute question qui lui serait soumise par le Corps des délègues ou par le Conseil exécutif.

b. Toute question surgissant de l'interprétation du Pacte établissant la Ligue.

c. Tout différend que, avec l'assentiment de la Cour et du Conseil exécutif, l'une quelconque des parties désirerait lui voir soumettre. 65

The innovation of Larnaude's suggestion revolved around sub-paragraph $b$. The provision was explicitly intended to transform the mooted Court into a "constitutional court" of the League, modelled on the Supreme Court of the United States. ${ }^{66}$ Clearly, this proposal was rejected. Orlando, with the support of Lord Cecil, thought that the interpretation of the Covenant was best left to the Organs which had the responsibility to apply it. ${ }^{67}$ In other words, they should interpret their own competence. The abandonment of this provision gave rise to a persistent scepticism as to whether to Court was competent to interpret the Covenant.

Concerns regarding the spectre of "compulsory adjudication by the backdoor" animated two further changes to the text of Article 14. Hurst and Miller prepared a revised text which distinguished between the Court's competence to determine disputes submitted to it by states and its ability to advise on questions referred to it by the organs of the League. ${ }^{68}$ Before the Final Drafting Committee, the two functions were disaggregated further. ${ }^{69}$ The advisory jurisdiction, referred to as such for the first time, was now delimited in a separate sentence, further differentiating it from the contentious jurisdiction. This new formulation was intended to emphasise, on the one hand, that the Court's two functions were distinct, while, on the other hand, confirming that, in both cases, the 'function to be exercised is a judicial one. 70

65 Miller, 'Drafting the Covenant Vol. 1 ' (n 53) 329.

66 Ibid.

67 Miller (n 55) 348-349.

68 Ibid 662; Miller, 'Drafting the Covenant Vol. 1' (n 53) 393.

69 Miller, 'Drafting the Covenant Vol. 1 ' (n 53) 406.

70 Ibid. 
The creation of the advisory function was radically innovative at the international level, ${ }^{71}$ and only weakly analogous to advisory bodies within municipal legal structures. ${ }^{72}$ It had been 'introduced in bare-outlines - and almost inadvertently' by the drafters of the Covenant. ${ }^{73}$ As such, the precise nature of the function, and, in particular, the nature of the bond it established between the League and the Court caused a series of controversies. These controversies would only multiply after it was decided, during the vetting of the Statute by the League organs, that the Court was to stand as an independent entity. ${ }^{74}$ During the drafting of the Court's Statute, as well as the formulation of the Rules of Procedure, the underlying uncertainties regarding the nature of the advisory function and the ambiguous relationship with the League would manifest themselves in the form of a very specific question: was the Court obliged to accept requests for advisory opinions?

The task of preparing the Statute was, of course, assigned to the Advisory Committee of Jurists. The main controversies concerned the Court's contentious jurisdiction and relatively little attention was paid to the advisory function. ${ }^{75}$ Nevertheless, draft Article 36 stated that the Court 'shall' render advisory opinions requested by the Council and the Assembly. ${ }^{76}$ The obligation imposed upon the Court to respond to requests for advisory opinions stood in contrast with the explicit provision for the Court to have the right to determine its own jurisdiction in contentious cases. ${ }^{77}$ Draft Article 36 would

71 Cf Manley Ottmer Hudson, The Permanent Court of International Justice: 1920-1942 (New York: The Macmillan Company, 1943) 484 ('The Permanent Court of International Justice') citing, eg, Article 15 of the Universal Postal Convention of October 9, 1874, which bestowed an advisory function on the International Bureau of the Universal Postal Union. Rather starkly, and contrary to more recent scholars, Hudson concluded that 'it cannot be said that the provision in Article 14 of the Covenant constituted a great innovation in judicial history.' Ibid 486.

72 Marika Giles Samson and Douglas Guilfoyle, "The Permanent Court of International Justice and the "Invention" of International Advisory Jurisdiction' in Malgosia Fitzmaurice and Christian Tams (eds), Legacies of the Permanent Court of International Justice (Brill Nijhoff, 2013) 41, 43-44.

73 Michla Pomerance, The Advisory Function of the International Court in the League and UN Eras (Johns Hopkins University Press, 1973) 40.

74 Hudson (n 71) 111, 120.

75 See, generally, Ole Spiermann, "Who Attempts Too Much Does Nothing Well": The 1920 Advisory Committee of Jurists and the Statute of the Permanent Court of International Justice' (2003) 73(1) The British Year Book of International Law 187 ("Who Attempts Too Much Does Nothing Well"').

76 Procéss Verbaux, Advisory Committee of Jurists [1920], 732.

77 Statute of the Permanent Court, Article 36(4). 
have explicitly denied the Court compétence de la compétence with respect to the advisory jurisdiction.

The Assembly's Third Committee, charged with reviewing the draft Statute, raised concerns about the feasibility of the distinction between 'questions' and 'disputes', drawn by Draft Article $36 .{ }^{78}$ Numerous amendments were suggested in order to make the Article satisfactory, but ultimately it was removed altogether. ${ }^{79}$ No further provision was included on the advisory function, but, prior to the deletion of draft Article 36, Fromageot argued that that "[t]he Covenant, in Article 14, contained a provision in accordance with which the Court could not refuse to give advisory opinions. It was therefore unnecessary to include a rule to the same effect in the constitution of the Court.' ${ }^{80}$ Fromageot's interpretation of Article 14 was by no means universally shared.

As the Court was drawing up its Rules of Court the American representative, John Basset Moore, re-opened the debate on the advisory jurisdiction in general and the issue of compétence de la compétence in particular. Moore argued that the very idea of an advisory function was incompatible with the nature of a Court of Justice. Moreover, '[i]t is evident that, to impose upon a court of justice the duty of giving advice, which those requesting it were wholly at liberty to reject, would reduce the Court to a position inferior to that of a tribunal of conciliation. ${ }^{81}$ Consequently, Moore contended that ' $[\mathrm{i}] \mathrm{t}$ is hardly compatible with this design that the Court should be obliged to render on request opinions lacking any element of authority or of finality.' ${ }^{\prime 2}$ However, unlike Fromageot, Moore considered that 'it is by no means clear that such an obligation has been imposed on the Court.'83 This proposal was not endorsed in the final draft, but, just as importantly, nor was any provision which further undermined the "judicial" character of the advisory jurisdiction.

This question of the compétence de la compétence was a manifestation of a much more fundamental question. What was the Court's function in rendering advisory opinions? The League Organs would approach the Court, 'not ... as plaintiffs or defendants, but rather as clients requesting the legal advice of their counsellor. ${ }^{84}$ However:

78 League of Nations 'Documents concerning the action taken by the Council of the League of Nations under Article 14 of the Covenant and the adoption by the Assembly of the Statute of the Permanent Court, 146.

79 Ibid 156.

8 o Ibid 156 .

81 John Bassett Moore 'The Question of Advisory Opinions: Memorandum by Mr Moore' [1922] PCIJ (Ser D), 383

82 Ibid.

83 Ibid.

84 Pomerance (n 73) 40. 
The fact that the Court, and not a mere committee of jurists, was to be the counsellor, and that the term "advisory opinion" was deliberately employed to imply a judicial function; the fact that the purpose of the advisory jurisdiction was to allow the League organs to clarify legal aspects of disputes brought before them for peaceful settlement, and that such disputes would necessarily entail parties with a stake in the Court's replies, parties whose views the Court might wish to ascertain - all militated against development of the advisory function as legal consultation pure and simple. ${ }^{85}$

The Permanent Court was, from the outset, a prisoner of the underlying tension between "the "lawyer-client" and "quasi-contentious" conceptions of the Court's advisory function. ${ }^{86}$ This underlying ambiguity led to dissensus across a wide range of procedural matters. For instance, should the Court's opinion be rendered publicly, or in private? Who, if anyone, ought to be given the opportunity to plead before the Court? Should interested states be given the right to appoint ad hoc judges? The consequence of these uncertainties meant that the greatest challenge facing the Permanent Court was 'to determine how it would discharge its judicial function, and it had to do so more or less from scratch. ${ }^{187}$ In practice, the Court demonstrated 'a disposition to confine its exercise of advisory jurisdiction within the limits of judicial action,' but was unwilling to indicate just how far the advisory jurisdiction 'was to be assimilated to procedure in contentious cases.' 88

The drafters of the Versailles settlement envisaged the post-war order as a political hierarchy with the Council at the apex of the institutional order. The institutions which predated the League were to be brought within its orbit and coordinated by the Secretariat. The Court's position was more ambiguous, and it had grown in autonomy throughout the drafting process. Nevertheless, its role, in so far as it was to be incorporated within the League, was subsidiary. However, by 1922, when the Court began to render opinions, this vision was already fraying. Article 24 quickly fell into near-desuetude, as independent institutions shunned centralised direction by the "political" League. Instead of a centralised, hierarchical system, the relationship "between the League and the multilayered world of international organizations [...] remained informal

85 Ibid (emphasis original).

86 Ibid 41 .

87 Iain Scobbie, 'The Permanent Court of International Justice, Arbitration and Claims Commissions' in Malgosia Fitzmaurice and Christian Tams (eds), Legacies of the Permanent Court of International Justice (Brill Nijhoff, 2013) 201, 207.

88 Hudson (n 71) 508 . 
from both sides. ${ }^{\prime 89}$ By pure happenstance, the ILO's early arrival in Geneva meant that it is established its own, autonomous secretariat. In Albert Thomas the ILO was governed by an independent minded figurehead who invoked the idea of an organic, living constitution in order to enable and legitimate the ILO's increasingly separate existence. The PCIJ was faced with profound questions regarding the nature of the institutional order and its own role within it: what was its relationship to the League? Was it subservient to the Council? Were international institutions, including the Court itself, organs of something greater than themselves or autonomous and distinct entities? This was the institutional terrain in which the Court rendered its earliest advisory opinions.

The Permanent Court as an 'Authoritative Interpreter'

In Competence of the ILO in regard to International Regulation of the Conditions of the Labour of Persons Employed in Agriculture ('Agricultural workers') the Permanent Court defined the object of its analysis in the following terms:

It was much urged in argument that the establishment of the International Labour Organisation involved an abandonment of rights derived from national sovereignty, and that the competence of the Organisation therefore should not be extended by interpretation. There may be some force in this argument, but the question in every case must resolve itself into what the terms of the Treaty actually mean, and it is from this point of view that the Court proposes to examine the question. ${ }^{90}$

On the basis of this passage, and, more broadly, the 'exclusively grammatico-logical basis'91 of the reasoning, it is not difficult to see why Agricultural workers is widely understood as being premised on a reductive, simplistic conception of international organisations; their "special nature" obscured by an exclusive focus on paper constitutions. ${ }^{92}$ In this section, I want to argue that this characterisation misrepresents the Permanent Court's position. Instead, it is argued that this passage is a manifestation of the first attempt of the Court to

\footnotetext{
89 Herren (n 14) 104.

90 Competence of the ILO in regard to International Regulation of the Conditions of the Labour of Persons Employed in Agriculture (Advisory Opinion) [1922] PCIJ Series B No. 2, 23 ('Agricultural Workers').

91 Jan Hendrik Willem Verzijl, The Jurisprudence of the World Court: A Case by Case Commentary, vol 1 (Brill Archive, 1966) 33 ('The Jurisprudence of the World Court').

92 See, eg, Klabbers, Advanced Introduction (n 16) $5^{2-53}$.
} 
reconcile the competing conceptions of the structure of international organization and how the Court should discharge its advisory jurisdiction. I'm going to refer to this initial mode as "authoritative interpreter"; signifying a conception of the judicial function that is at once conservative and assertive.

To begin with, it is clear that the Court did not base its conclusions on an exclusively paper-based conception of the ILO. The passage cited above is immediately followed by the Court taking a second cue. Namely, that the object of the treaty was to establish 'a permanent labour organization. ${ }^{93}$ This purpose, moreover, 'in itself strongly militates against the argument that agriculture ... is to be considered as left outside the scope of the International Labour Organization because it is not expressly mentioned by name. 94 Thus, from the outset, the Court conceived of the ILO in a dualistic fashion: simultaneously defined by the dialectic relationship between its textual constitution and its material existence. ${ }^{95}$ While reference to the permanence of the ILO may appear trite to modern observers, the frequency of its invocation, both in titles and the description of institutions, speaks of the centrality of permanence to the way that institutions were perceived to be "special."

Moreover, examining the pleadings of the various interested parties in both Agricultural workers and Agricultural production, we can, moreover, get a clearer sense of the way that the role of the Court, and the wider structure of international organisation, were contested. As mentioned above, the Court's assumed function in these cases can usefully be thought of as an authoritative interpreter, a mode that is simultaneously conservative and assertive. The conservatism of this posture becomes clear in relation to the remnants of the 'constitutional' vision of Versailles at work in the arguments of those who opposed ILO action in the field of agriculture. The "constitutional vision" portrayed by Lapradelle and Maenhaut had two key facets: it presupposed a rational division of labour between the various organs of international organisation and granted the Court a special position as the arbiter of this system. The presumed sectoral division of labour was manifest in the emphasis placed on the putative need to demarcate the respective provinces of the ILO and the International Institute of Agriculture (IIA). Firstly, M. Maenhaut, Counsel for the International Agricultural Commission, raised what might be termed a "systematic" critique of the ILO's activities in relation to agriculture. In essence, he argued that the competence of the ILO ought to be construed in relation to the competencies of the already existing International Institute of

93 Agricultural Workers (n 9o) 23 (emphasis original).

94 Ibid 23-25.

95 See, also, the references to the permanence of the ILO at ibid 27, 33. 
Agriculture. ${ }^{96}$ Thomas, in response, represented this issue as one of amicable cooperation, rather than institutional conflict. ${ }^{97}$ Indeed, the reason France sought a further opinion on the ILO's competences regarding production was to provoke the Court into laying down clear boundaries between the respective competences of the ILO and the IIA. ${ }^{98}$

In light of this, let us look afresh at a second passage, this time orientating the Court's opinion in Competence of the ILO to Examine Proposals for the Organization and Development of the Methods of Agricultural Production ('Agricultural production'), which, likewise, appears to support the view that the Permanent Court simply regarded institutions as treaties.

The answer to the question whether the consideration of proposals for the organisation and development of the means of agricultural production... fall within the competence of the International Labour Organisation, must likewise depend entirely upon the construction to be given to the same treaty provisions from which, and from which alone, that Organisation derives its existence and powers. ${ }^{99}$

The Court's opinion in Agricultural production makes no reference to the IIA and, moreover, the foregoing passage clearly demonstrates the rejection of the idea that an international organisation's competences were determined by its place in the overall structure of international organisation. The powers of international organisations were defined solely by reference to their own constituent instrument. By rejecting the idea of an underlying fabric of international organisation, the Court implicitly renounces any role for itself as the arbiter of said system. The conservatism of this posture is manifest in the way

96 M. Maenhaut, Speeches Made and Documents Read before the Court, PCIJ Series C, Co1, $216-7$.

97 M. Thomas, ibid, $265^{-6}$.

98 "Only in this way is it possible to realise that the Governing Body of the International Labour Office, the Conference, in a word all the machinery of the International Labour Organisation, once they set foot within the domain of agriculture, must define the limits of their competence in conjunction with the Agricultural Institute. Now, where have the limits of this competence ever been defined? Where has an attempt been made to do so? These are considerations which may present themselves to the Court during its deliberations, when, thanks to the action taken by the French Government, with the support of the Council, it will be able to consider the question of agricultural labour as a whole." M. Lapradelle, ibid, 308.

99 Competence of the ILO to Examine Proposals for the Organization and Development of the Methods of Agricultural Production (Advisory Opinion) [1922] PCIJ Series B No. 3 53-55 ('Agricultural Production') (emphasis added). 
that the Court establishes itself as the authoritative interpreter of positive legal texts rather than foundational principles or latent structure.

Nevertheless, the Court's assumption of the function of authoritative interpreter is also assertive. It is assertive in the sense that it excludes the interpretations, arrived at by the ILO itself, in the determination of the limits of the competence of the organisation. This is vividly illustrated in two ways. Firstly, it is only in recounting the procedural history of the dispute that the Court provides any hint of an acknowledgement that the ILO may or may not possess the authority to resolve, internally, questions regarding the boundaries of its competence. The Court simply observed that the Conference had twice voted in favour of the proposals to regulate agricultural workers, thus 'reaffirming' its competence to do so. ${ }^{100}$ However, the Court treated the ILO's reaffirmation of its competence as a mere procedural fact lacking in any normative force. Secondly, while the Court takes heed of various acts and decisions taken under the framework of Part XIII of the Treaty of Versailles, crucially, these are framed as subsequent practice of the parties to an agreement. Effectively, the ILO is read out of the interpretation of its own constituent instrument.

The Court's opinion in Nationality Decrees can be understood as a continuation of the posture of authoritative interpreter. ${ }^{101}$ What makes this decision significant, particularly in light of persistent debates regarding the authority of the Court to interpret the Covenant, is that the Court adopted an analogous posture vis-à-vis the League Council. The dispute concerned the applicability of Article 15(8) - the domestic jurisdiction exception to the Council's dispute settlement function - to a dispute between France and Britain regarding the compulsory assignation of French nationality to British nationals in French protectorates. Again, Lapradelle, the French Counsel, sought to cast the Court in a constitutional light, both as a check against unwarranted interferences with sovereign liberty ${ }^{102}$ and by inviting it to author general pronouncements regarding the nature of protectorates in international law. ${ }^{103}$ By contrast the British Counsel narrowed the question, merely inviting the Court to pronounce on whether Article ${ }_{15}(8)$ applied to the dispute at hand. Further demonstrating the conservatism of its perspective of authoritative interpreter, the Court opted for the latter course.

\footnotetext{
100 Agricultural Workers (n 90) 19 (emphasis added).

$101 \quad$ Nationality Decrees (n 44).

102 M. Lapradelle, Speeches Made and Documents Read before the Court, PCIJ Series C, Co2, $70-4$.

103 Final Conclusions Submitted by the French Government, ibid, 242.
} 
The real controversy inside the Court in Nationality decrees concerned the assertiveness of the Court in providing an authoritative interpretation of the Covenant. The question of whether a matter was 'solely' within a states' jurisdiction was 'an essentially relative question' which 'depends upon the development of international relations.' ${ }^{104}$ While nationality was not, 'in principle, regulated by international law' states could contract international undertakings which meant that its discretion was limited by rules of international law.'105 However, rather than proceeding on to determine whether, in fact, France had limited its sphere of discretion regarding nationality in relation to Britain, the Court went on to deliver an authoritative interpretation of Article 15 in the abstract. Article 15, the Court argued 'establishes the fundamental principle that any dispute likely to lead to a rupture ... shall be laid before the Council.'106 Under this provision, the Council possessed a 'very wide competence', and, consequently, the exception provided by paragraph 8 , 'does not lend itself to an extensive interpretation. ${ }^{107}$ ' $[\mathrm{T}]$ he mere fact that a State brings a dispute before the League of Nations does not suffice to give this dispute an international character', nor was 'the mere fact that one of the parties appeals to engagements of an international character.' ${ }^{\prime 08}$ Crucially:

$[\mathrm{O}]$ nce it appears that the legal grounds (titres) relied on are such as to justify the provisional conclusion that they are of juridical importance for the dispute submitted to the Council, and that the question whether it is competent for one State to take certain measures is subordinated to the formation of an opinion with regard to the validity and construction of these legal grounds (titres), the provisions contained in paragraph 8 of Article 15 cease to apply. ${ }^{109}$

Having defined the question in such as fashion, it was of little surprise that the Court found that the various treaty obligations raised by Britain were sufficient to render Article 15(8) inapplicable. Within the Court reactions were mixed. Judge Moore, in particular, was scathing in his criticism, not merely regarding the substantive position advanced, but at the very fact that the Court had proffered its views on the matter.

$\begin{array}{ll}104 & \text { Nationality Decrees (n 44) } 24 . \\ 105 & \text { Ibid. } \\ 106 & \text { Ibid. } \\ 107 & \text { Ibid 25. } \\ 108 & \text { Ibid 25-6. } \\ 109 & \text { Ibid 26. }\end{array}$


I am astonished to find that the revised draft actually puts the Court ... in the place of the Council, and then proceeds through a number of pages ... to elaborate and lay down rules by which the Council must be governed. Not only is this in itself improper, but the rules laid down are, in my opinion, quite inadmissible, and would virtually deprive the Council of the power to find that a matter is within the exclusive competence of one of the parties...

...some of our colleagues apparently can't be brought to accept the distinction, which I conceive to be fundamental, between holding that the particular matter now before the Court is not one of exclusive competence, and laying down a general rule for the government of the Council in all conceivable cases. ${ }^{110}$

Moore's critique was clearly targeted at the assertiveness of the Court's assumption of the posture of authoritative interpreter. Rather than simply disposing of the question at hand, the Court laid out a general scheme for the interpretation of Article 15(8) which substantially curbed the discretion of the Council. This is all the more surprising in light of the fact that Article 15(8) explicitly granted the Council the authority to determine whether or not the dispute was international in character.

In the foregoing cases, the PCIJ resolved, or perhaps avoided, thorny questions regarding the ambiguous authority it held over other institutions by assuming the function of an authoritative interpreter. In doing so, the Court did not place any real emphasis on the ability of institutions to decide, for themselves, the limits of their competence. That is not to say the idea was absent. In Agricultural workers, the Permanent Court treated the ILO's reaffirmation of competence as a procedural fact. In Nationality decrees the Court did acknowledge that it was the responsibility of the Council to determine whether Article 15(8) was applicable, but only once it had, on its own volition, formulated abstract rules which curtailed the Council's discretion. What is striking about these opinions is not a "weak theory" of international organizations, but rather the relationship that the Court assumes in relation to the institution in question. The organizations are reduced to the treaty because the Court adopted the perspective of an authoritative interpreter - taking refuge in, assuming authority over, legal texts. Organizations appear two-dimensional because they are viewed "from above". With respect to the wider institutional

110 Moore to Finlay, 29 January 1923, Moore papers 177, quoted in Spiermann, International Legal Argument (n 44) 158. 
order, while the Court had implicitly challenged the interpretative authority of the Council over the Covenant, the dissenting voices remained internal.

The Status of Eastern Carelia, USSR v Finland ('Eastern Carelia') opinion is widely recognised to be one of the most significant and enigmatic of the PCIJ's decisions. ${ }^{111}$ Debate continues regarding the precise meaning of the so-called "Eastern Carelia principle", in particular whether the Court regarded state consent as a necessary condition for the lawful exercise of its advisory function. ${ }^{112}$ However, I'm less concerned with the substantive principle espoused by the Court than the posture adopted in delivering it. On the one hand, Eastern Carelia represented a continuation of the Court's previous opinions in the sense that the Court adopted an authoritative interpretation of the Covenant. However, at the same time, by rejecting the request for an advisory opinion the Court asserted its compétence de la compétence, emphasising its autonomy from the League.

In the report preceding the request for an advisory opinion Salandra, the Council Rapporteur, argued that 'the Council undoubtedly has the right to refer' the Eastern Carelian dispute to the Court. ${ }^{113}$ This claim was supported by the argument that there was 'no restriction limiting the Council's right to ask advisory opinions on any dispute or point which it desires to submit to the Court.'114 Lastly, Salandra sought to pre-empt any reservations that the judges on the bench may have held by reiterating 'that the Court is not asked to consider the question of Eastern Carelia as a dispute in which Finland and Russia are 'parties' in the legal sense of the word.'115

Needless to say, the Court disagreed with the Council's interpretation and declined to give an opinion on the status of Eastern Carelia. The terms of Article 17, providing for a form of ad hoc League membership in relation to specific issues, reflected the 'fundamental principle of international law' that 'no State can, without its consent, be compelled to submit its disputes with other States either to mediation or arbitration, or to any other kind of pacific

111

112

113

114

115

Status of Eastern Carelia, USSR v Finland (Advisory Opinion) [1923] PCIJ Series B No. 5 Premanent Court of International Justice No. 2 ('Eastern Carelia').

See, eg, Philip Burton, 'Searching for the Eastern Carelia Principle', (2019) 8:1 ESIL Reflections.

Report of M. Salandra, League of Nations Official Journal, 1923, p. 663

Ibid.

Ibid. 
settlement.'116 The only way a dispute could be settled by international organs was through the consent of the relevant states. Therefore, Russia's repeated refusal to consent to the process meant that the Court was unable to render an opinion. ${ }^{117}$ The Court had again 'put itself in the place of the Council', to borrow Moore's phrase, and delivered an authoritative interpretation of Articles 14 and 17 of the Covenant of the League. On this occasion, however, Moore was one of the key sponsors of the text eventually adopted by the Court. Moore's support was based both out of fear that the advisory jurisdiction would create a 'backdoor' for compulsory adjudication and also on his view, discussed above, that the Court must necessarily have the ability to decline requests for advisory opinions.

In terms of the basic framework underpinning this study, the Eastern Carelia opinion represents a critical juncture. The Permanent Court retained the posture of an authoritative interpreter but it did so in a way that brought it into direct confrontation with the League Council. In the wake of the Eastern Carelia opinion, in what Moore regarded as a 'scarcely veiled admonition,'118 the Council sought to mitigate the wider implications of the Opinion and re-establish its own primacy with regards to the interpretation of the Covenant. ${ }^{119}$ The political hierarchical vision which informed the drafting of the Covenant, already threatened by the increasingly independent ILO and the unwillingness of pre-League institutions to organise under its auspices, was dealt a fatal blow. The PCIJ used the Eastern Carelia opinion unambiguously announce its independence from the League, particularly to closely watching American audiences who, while renouncing the League, had not yet given up hope of acceding to the Court's Statute. Up until this point, the Permanent Court had repeatedly demonstrated its willingness to assume the mantle of authoritative interpreter, it had shown little regard for the interpretations of institutions regarding their own competencies.

The Permanent Court as an Interpreter amongst Many

By the 1925 Exchange of Greek and Turkish Populations (Lausanne Convention VI, January 3oth, 1923, Article 2) ('Population Exchange') advisory opinion the

\footnotetext{
$116 \quad$ Eastern Carelia (n 111) 27.

$117 \quad$ Ibid 28.

118 Moore to Huber 18 September 1926 Huber papers 24.1, Moore papers 172, quoted in Spiermann, International Legal Argument (n 44), 169.

11 Annex 576a C, 1923 LNOJ 15O1, 1502.
} 
Permanent Court adopted a visibly different posture. ${ }^{120}$ The Court was far less assertive in staking out its own interpretative authority over the constituent instrument and placed far greater emphasis on existence of an apparatus for resolving disputes internally. The dispute arose regarding the correct interpretation of the term 'established' in the context of the Greco-Turkish population exchange. ${ }^{21}$ The request, and basic issues at stake, can be usefully compared to Nationality Decrees: it concerned the boundaries of an institutions' competence vis-à-vis the national legal order. However, the way the Court approached the request was fundamentally different. In Nationality Decrees a specific request resulted in a detailed authoritative interpretation of Article 15 and its place in the Covenant as a whole. In Population Exchange an invitation to provide a detailed authoritative interpretation was rebuffed. Rather than engage in the substantive issues raised by the request the Court highlighted the provisions granting the Mixed Commission the authority to resolve questions of interpretation internally, by recourse to the decision-making procedures provided for in the treaty.

The request was composed of two questions. The first concerned the 'meaning and scope' of the word 'established' as employed in Article 2 of the population exchange agreement. The second asked for further elaboration regarding the conditions that persons must fulfil in order to fall within the ambit of the term 'established'. The crux of the first question was whether the concept of established implicitly referred to the concept of domicile as found in the Turkish legal system. The Court found that it did not and, consequently, Turkish courts had no role to play in the matter. ${ }^{122}$ "The Mixed Commission [...] is alone competent to investigate [...] whether a Greek inhabitant of Constantinople is 'established' in conformity with Article 2 of the Convention.' ${ }^{123}$ The question of how to interpret 'established' lay at the heart of the request for an opinion, but the Court's answer is astonishingly vague: it required that, in order to qualify, individuals' residence "must be of a lasting nature and must have been so" at the relevant time. ${ }^{124}$ The degree of stability was 'incapable of exact

Exchange of Greek and Turkish Populations (Lausanne Convention VI, January 3oth, 1923, Article 2) (Advisory Opinion) [1925] Permanent Court of International Justice Series B. No. 10 ('Population Exchange'). the Greek-Turkish Population Exchange' (2011) 24(4) Leiden Journal of International Law 823 ('Fabricating Fidelity'). 
definition'125 and the Court was unable to 'foresee all the various cases with which the Mixed Commission may be confronted. ${ }^{126}$ For example, the Court declined to examine the play between the requirement that persons be established and other values such as protecting the integrity of families: 'The powers conferred upon the Mixed Commission [...] enable that body [...] to find an equitable solution for any dispute points.' ${ }^{127}$ The authority of the Mixed Commission to resolve such disputes was reinforced in the closing passage of the Opinion. ' $[\mathrm{H}]$ aving regard to the very wide powers possessed by the Mixed Commission, that body may decide in each case as to the manner in which the fulfilment of the conditions above mentioned is to be established. ${ }^{128}$

In the foregoing analysis, I have sidestepped the role that Article 12 of the Population Exchange agreement played in the Court's reasoning. This provision expressly granted the Mixed Commission 'full power to ... decide all questions to which this Convention may give rise'. I have done so in part because an analogous provision in the Covenant did not prevent the Court from laying down detailed rules curtailing the Council's discretion under Article 15 and in part because the lack of such a provision did not prevent the Court from making the same point, even more resoundingly, in its next decision regarding the ILO.

The Permanent Court's advisory opinion in Competence of the ILO to Regulate Incidentally the Personal Work of the Employer ('Personal work') is, in my view, its most significant contribution to the law of international organisations. This significance lies in the fact that the Court located the authority to interpret Part XIII of the Peace Treaty in the decision-making procedures established by that Treaty: the constitution was to be interpreted by the constituted. The subject matter was closely related to Advisory Opinion 3, which had affirmed the ILO's ability to propose conventions which produced incidental effects beyond the Organisations competence ratione matireae. The request in Personal work sought the Court's views on whether this ability extended to the ILOs competence ratione personae. We must take heed of this repetition when accounting for the radical departure in style, but while it might account for the adoption of a different approach, this cannot, in and of itself, account for the approach which was adopted. Rather, it is argued here, that the shift in reasoning is best understood as the manifestation of the evolution of the Court's understanding of its own function; away from the authoritative interpreter of

\begin{tabular}{ll}
\hline 125 & Ibid. \\
126 & Ibid 24. \\
127 & Ibid. \\
128 & Ibid 25.
\end{tabular}


a system of international organisation, towards being an institution operating in the midst of others. ${ }^{129}$

The Opinion began by re-covering ground that was already familiar from the agricultural opinions. However, the emphasis quickly shifted from the provisions which defined the ambit of the ILO's competence to the provisions which laid out its decision-making procedure. The key passages are worth quoting at length.

the Treaty provides the means of checking any attempt on the part of the Organization to exceed its competence. In this way, the High Contracting Parties have taken precautions against any undue extension of the sphere of activity indicated by the Preamble....

it is entirely in conformity with the broad wording of the above-mentioned Preamble that it should be left to the Labour Conference itself to decide if and in what degree it is necessary and opportune to embody in a proposed Convention provisions destined to secure its full execution....

Controversy, of course, may arise, at different stages of the procedure of the International Labour Organization, as to whether a specific proposal for the regulation of the personal work of the employer (patron) would be primary rather than "incidental", and therefore alleged to be outside the competence of the Organization. Obviously, such a question involves the exercise of judgment by the proper authorities on the circumstances of each case as it may arise. ${ }^{130}$

In terms of the breadth of competence, or the power to make 'incidental' regulations, Personal Work doesn't represent any fundamental development from prior interpretations. However, the emphasis is fundamentally different. What the Court makes explicit in Personal work is that it is that ILO is empowered to interpret its own constituent instrument, 'in the first place at least.'131 Furthermore, taken cumulatively, the decisions of the ILO - as an institution - could provide evidence as to whether a matter lay within the institution's

\footnotetext{
129 This formulation is drawn from Scobbie (n 87).

130 Competence of the ILO to Regulate Incidentally the Personal Work of the Employer [1926] PCIJ Series B No. 13 23-24 ('Personal Work').

131 This phrase deliberately invokes the terms used by the PCIJ to qualify the general principle of compétence de la compétence with respect to "jurisdictional", or judicial, bodies in its second advisory opinion on the Greco-Turkish Mixed Commission and, later, when reconstituted as the ICJ, with respect to the (non-judicial) General Assembly of the United Nations in Certain Expenses.
} 
competence. ${ }^{132}$ The pleadings before the Court demonstrate the significance of these steps. Borel, representing L'organisation Internationale des Employeurs Industriels, argued that any "transformation" of the text could only be achieved through the process of amendment highlighted provided for under Article 422: 'l'organisation internationale n'est pas maitresse de cette compétence. Organisation internationale ne peut pas dire: “C'est moi qui décide."'133 Even more tellingly Albert Thomas sought to disavow any claim that the ILO were the masters of the text, bowing to 'l'avis souverain' of the Court. ${ }^{134}$ Similarly, much hay had been made, by proponents of the regulation, of the fact that no state representatives had objected. ${ }^{135}$ However, breaking with its previous reasoning, the Court declined to grant state representatives any special status within the International Labour Conference. It was the practice of the organisation as a whole which mattered. The Court declined to locate ultimate interpretative authority over the ILO's constituent instrument either in states or to claim it for itself. The distance the Court had travelled was made clear when it concluded the Opinion by stating that expressing its views on the limits of 'any discretionary powers which the International Labour Organisation may possess $[\ldots]$ would exceed [the Court's] own competency.'136

The Permanent Court's opinion in Personal work marked the birth of a recognisably modern law of international organizations. The Court's adoption of a more limited judicial function, highlighting the autonomous decision-making capacities of the ILO and recognising the normativity of the Organization's decisions on competence, had deep implications. Part XIII of the Treaty of Versailles not only empowered the ILO Conference to decide whether or not a proposal was desirable, it provided the framework for contesting the legality

132 Personal Work (n 130) 20. For an analysis of 'practice of the organisation, see, for example, Salo Engel, "Living' International Constitutions and the World Court (the Subsequent Practice of International Organs under their Constituent Instruments)' [1967] 16 International and Comparative Law Quarterly 865; Christopher Peters, 'Subsequent Practice and Established Practice of International Organizations: Two Sides of the Same Coin' [2011] 3 Goettingen J. Int'l L. 617; Julian Arato, 'Treaty Interpretation and Constitutional Transformation: Informal Change in International Organizations' [2013] 38 Yale J. Int'l L., 289 .

133 M. Borel, Speeches Made and Documents Read Before in Court, PCIJ Series C, C12, 29-30.

134 M. Thomas, ibid, 53.

135 M. Serrarens, ibid, 48-5o, M. Thomas, ibid, 6o.

136 Personal Work (n 130) 24. 
of such proposals. Despite the Permanent Court's insistence that it was unconcerned 'whether the functions entrusted to the ILO are or are not in the nature of delegated powers, ${ }^{137}$ the emphasis on the ILO's autonomy in the exercise of its powers have led to numerous scholars identifying Personal work as the "origin" of the attributed powers doctrine. ${ }^{138}$ Similarly, the Permanent Court's finding that the ILO's decisions on competence were relevant to any judicial determination of the ILO's competence represented the first expression of the concept of practice of the organization. Moreover, Part XIII of the Treaty of Versailles was no longer framed exclusively as a treaty. As per Sinclair, ' $[\mathrm{i}] \mathrm{n}$ a rhetorical move that was by now becoming familiar in connection with the ILO, the Court rationalized its reference to subsequent practice by likening Part XIII to a constitution.'139

This shift was crucial in terms of securing the autonomy of international organizations in the classical sense: from their member states. ${ }^{140}$ But the shift was contingent upon the Court accepting a more limited judicial function, enabling space for organizations to interpret their own constitutions and recognising that the decisions of international organizations possessed normative force, even if they lacked in finality. In this sense, organizations not only became autonomous from their member states, but, additionally, they became autonomous from the Court as an authoritative interpreter. They became the masters of their own constitutions. This transformation did not come about because of any radical insight into what it meant to be an international organization, but rather what it meant to be an international court.

The arrival of an international Court of Justice limited the residual right of auto-interpretation held by states. It did so in a partial, limited fashion: the Court's decisions would only bind states which had consented to its jurisdiction and were party to the case at hand. However, the shifting approach adopted by the PCIJ with respect to other institutions altered the traditional right of auto-interpretation in ways which were more complex than simply creating an adjudicator-adjudicated binary. The effect of its evolving function resulted in the recognition of a plurality of interpreters at the international level, where ultimate authority was difficult to locate, if indeed it existed at all.

\footnotetext{
$137 \quad$ Ibid 23.

138 See, eg, Klabbers, 'Life and Times' (n 17) 296-297; Engström (n 24) 3 o.

139 Sinclair, To Reform the World (n 7) 54.

140 Jean d'Aspremont, 'The Multifaceted Concept of Autonomy of International Organizations' in Richard Collins and Nigel D White (eds), International Organizations and the Idea of Autonomy: Institutional Independence in the International Legal Order (Routledge, 2011) 63, 63 .
} 
It in this liminal space of legality where we can find the modern conundrums of the law of international organizations. Whether the implied powers doctrine contains any boundaries, or whether its simply provides post-hoc authorisation for whatever institutions have already done. Whether there is sufficient room between law and interpretation for ultra vires to play any meaningful role. Whether, and in what ways, courts, national as well as international, can get involved. The particular hue of these debates in contemporary discourses are not necessary consequences of the special nature of international organizations, whatever that may be. Rather they are functions of the ways that international organizations are understood in the wider system of international organization.

\section{Acknowledgements}

I wish to thank the participants at the University of Glasgow Postgraduate Conference and the members of Manchester International Law Centre for comments on earlier drafts of this paper. Additionally, I am indebted to David Rossati and Richard Collins for their insights into the paper, and, especially, my doctoral supervisors Jean d'Aspremont and Iain Scobbie for their invaluable assistance. 